Ф.В. Гладких, Г.В. Кулініч

\title{
Порівняльна характеристика гомеостатичних зрушень у пацієнток з фібротичними та дегенеративними пізніми радіаційними ускладненнями променевої терапії з приводу раку шийки матки
}

\author{
ДУ «Інститут медичної радіологї̈ ім. С.П. Григор’єва Національної академії медичних наук Українџ, Харків \\ Одержано: 18.09 .2019 \\ Прийнято до друку: 27.12.2019 \\ DOI: $10.32471 /$ clinicaloncology.2663-466X.36-4.26746
}

\begin{abstract}
Променева терапія $\epsilon$ важливою складовою лікування хворих на рак шийки матки (РШМ), проте у зв'язку з особливостями синтопії шийки матки, прямої кишки, сечового міхура, сечоводів та ін. променевому навантаженню піддаються практично всі органи малого таза. Це є передумовою розвитку місцевих променевих пошкоджень м'яких тканин та органів, які потрапляють у зону опромінення. Мета - провести порівняльний аналіз клініко-лабораторних показників пацієнток з пізніми радіаційними ускладненнями фібротичного та дегенеративного ґенезу після променевої терапії з приводу Ршм для виявлення критеріїв прогнозу вектора розвитку пізніх променевих ускладнень (ППУ). Матеріали і методи. Проведено ретроспективний аналіз 254 історій хвороби пацієнток зі злоякісними новоутвореннями шийки матки. Відібрано 73 історії хвороби пацієнток, розподілених на дві групи: Ф (41 пацієнтка) - хворі з фібротичними ППУ після лікування та Д (32 пацієнтки) - хворі з дегенеративними ППУ після лікування. Результати. Аналіз динаміки гематологічних показників показав, що на тлі проведення променевої терапії (ПТ) у хворих на РШМ з фібротичними ПпУ відмічалося статистично вірогідне збільшення кількості еритроцитів на 5,7\%, підвищення гемоглобіну - на 9,1\%, гематокриту - на 3,9\% та підвищення швидкості осідання еритроцитів (ШОЕ) на $33,3 \%$, у той час як у пацієнток з дегенеративними ПпУ аналогічні показники мали протилежну тенденцію до змін - кількість еритроцитів зменшилася на 6,3\%, рівень гемоглобіну знизився на 0,8\%, гематокрит - на 7,3\%, а ШОЕ - на 16,7\% відносно показників до ПТ. Крім того, встановлено, що кількість лейкоцитів мала тенденцію до зменшення у пацієнток обох груп, проте у хворих з фібротичними ПпУ вдвічі перевищувала аналогічний показник пацієнток з дегенеративними ППУ та становила відповідно 6,0 та 12,0\%. Характеризуючи динаміку біохімічних показників хворих на РШМ з ППУ, варто відзначити, що маркери цитолізу аланінамінотрансферази (АлАТ) та аспартатамінотрансферази (АсАТ) мали різний вектор змін. Так, у пацієнток з фібротичними ПпУ рівень АлАт зріс на 10,1\%, а АсАт на $16,4 \%$, в той час як у пацієнток з дегенеративними ППУ рівень АлАт знизився на 21,1\%, а АсАт - на 7,4\%. Вказані зміни узгоджуються з даними про розвиток цитолітичного синдрому на тлі дегенеративних ППУ. Крім того, у пацієнток обох груп відмічено співставне зниження білірубіну відповідно на 11,5 та 11,0\%. Також встановлено, що у пацієнток $з$ фібротичними ППУ на тлі ПТ статистично вірогідно підвищився рівень сечовини на 35,7\% та рівень креатиніну - на 6,5\%. Висновки. У пацієнток з РШМ фібротичні та дегенеративні пізні променеві ускладнення визначено у 32,3 та 25,2\% пацієнток відповідно. Фібротичні пізні променеві ускладнення у хворих на РШМ вдвічі частіше відмічають на тлі надмірної маси тіла, ніж на тлі її дефіциту - відповідно 24,4 та 12,2\% пацієнток. Відношення шансів розвитку фібротичних ПпУ щодо дегенеративних після оперативного компонента лікування становить 2,8 0,49 (95\% ДІ 1,1-7,2).
\end{abstract}

Ключові слова: рак шийки матки; променева терапія; пізні променеві ускладнення; променевий фіброз; променева виразка.

Рак шийки матки (РШМ) - одна з найпоширеніших форм злоякісних новоутворень жіночих статевих органів. В Україні, як і у світі, РШМ займає 2-ге місце після раку грудної залози серед причин смерті від злоякісних новоутворень у жінок [1, 5]. На сьогодні до основних методів лікування РШМ належать променева терапія (ПТ), оперативне лікування, хіміотерапія та комбінації вказаних методів [2, 5, 6].

ПТ є важливою складовою лікування хворих на РШМ, проте у зв'язку з особливостями синтопії шийки матки, прямої кишки, сечового міхура, сечоводів та ін. променевому навантаженню піддаються практично всі органи малого таза. Це $є$ передумовою розвитку місцевих променевих пошкоджень м'яких тканин та органів, які потрапляють у зону опромінення (променевий фіброз м'яких тканин, променева виразка, променевий остеопороз та ін.). До причин розвитку променевих ускладнень належать застосування сумарних вогнищевих доз, які перевищують толерантність оточуючих тканин до дії іонізуючого опромінення, сумація полів опромінення при місцево-поширених формах РШМ, повторне опромінення при рецидивуванні, помилки в плануванні ПТ, індивідуальна чутливість пацієнта, супутня патологія та ін.

За термінами виникнення розрізняють ранні (упродовж перших 100 днів після ПТ) та пізні (від 3 міс після ПТ і більше) променеві ускладнення. Така різниця у строках виникнення зумовлена відмінностями їх патогенезу. За даними літератури пізні променеві ускладнення (ППУ) зумовлені пошкодженням генетичного апарату клітин радіорезистентних тканин з низькою проліферативною активністю - ендотелію судин, м'язової, нервової, кісткової та інших тканин. У цих тканинах і органах не виявляють жодних ознак пошкодження ні відразу після опромінення, ні в найближчі терміни після нього. Однак променеві пошкодження, що виникли в хромосомному апараті клітин цих тканин, під час наступних актів поділу проявляються виникненням нежиттєздатних клітин. Поступово ці зміни призводять до непоправних клітинним втрат, облітерації і тромбозу судин, склеротичних та інших змін [3, 4].

Механізм розвитку радіаційно-індукованого фіброзу (РІФ) подібний до будь-якого хронічного загоєння ран. Окрім прямого пошкодження макромолекули дезоксирибонуклеїнової кислоти (ДНК), має значення й утворення вільних радикалів та як наслідок - окиснювальний стрес у тканинах. Пошкоджені клітини вивільняють молекули хемоатрактантів, які викликають неспецифічне запалення. Важливе значення у патогенезі РІФ належить трансформуючому фактору росту $\beta$ (transforming growth factor beta - TGF- $\beta$ ), який відповідає за вироблення фібробластів з кісткового мозку та їх диферен- 
ціацію в міофібробласти, завдяки чому фенотипові зміни фібробластів призводять до посилення експресії актину $\alpha$-гладкої мускулатури (Alpha-smooth muscle actin - $\alpha$-SMA) $з$ подальшим перетворенням на протоміофібробласти та можливим дозріванням у міофібробласти. У відповідь на наступну дію TGF- $\beta$ міофібробласти виробляють надлишок колагену, фібронектину та протеогліканів, що й призводить до ущільнення тканини. Крім того, надлишок колагену сприяє поступовому зниженню васкуляризації з подальшою ішемією, атрофією та некрозом, що проявляється дистрофічно-дегенеративними змінами тканин [7, 8].

Крім того, ППУ за характером поділяють на запальні (променевий цистит, променевий ректит, променевий уретрит, променевий ентероколіт, променевий ректосигмоїдит та ін.), фібротичні (внутрішньотазовий променевий фіброз, фіброз шкіри та підшкірної клітковини полів опромінення та ін.), дегенеративні (променеві виразки, нориці та ін.) та гематологічні $[3,4]$.

Мета роботи - провести порівняльний аналіз клініколабораторних показників пацієнток з пізніми радіаційними ускладненнями фібротичного та дегенеративного генезу після променевої терапії з приводу РШМ для виявлення критеріїв прогнозу вектора розвитку ППУ.

\section{МАТЕРІАЛИ ТА МЕТОДИ ДОСЛІДЖЕННЯ}

Проведено ретроспективний аналіз 254 історій хвороби пацієнток зі злоякісними новоутвореннями шийки матки (відповідно до критеріїв включення та критеріїв виключення у/із дослідження), які перебували на стаціонарному лікуванні в ДУ «Інститут медичної радіології ім. С.П. Григор'єва Національної академії медичних наук (НАМН) України» за період 1994-2018 рр. Критерієм включення у дослідження було комбіноване лікування при РШМ, яке включало ПТ. Для подальшого дослідження відібрано 73 історії хвороби пацієнток, розподілених на 2 групи: Ф (41 пацієнтка) - хворі з фібротичними ППУ після лікування та Д (32 пацієнтки) - хворі з дегенеративними ППУ після лікування.

Відповідно до мети та завдань дослідження проведено оцінку показників загальноклінічного аналізу крові - еритроцити (red blood cells - RBC; • $10^{12} /$ л), гемоглобін (hemoglobin - Hb; г/л), кольоровий показник (КП), середній вміст гемоглобіну в еритроциті (mean cell hemoglobin - MCH; пг), середній об'єм еритроцита (mean corpuscular volume - MCV; фл), тромбоцити (platelets - PLT; • $\left.10^{9} / л\right)$, гематокрит (hematocrit HCT; \%), лейкоцити (white blood cells - WBC; • $\left.10^{9} / л\right)$, швидкість осідання еритроцитів (ШОЕ; мм/год); біохімічні показники - загальний білок (г/л), сечовина (ммоль/л), креатинін (мкмоль/л), білірубін (мкмоль/л), глюкоза (мкмоль/л), аланінамінотрансфераза (АлАТ, мкмоль/год•л), аспартатамінотрансфераза (АсАТ, мкмоль/год•л), а також показники системи згортання крові - протромбіновий час (ПТЧ; с), протромбіновий індекс (ПТІ; ум. од.), активований частковий (парціальний) тромбопластиновий час (АЧТЧ; с), час згустку (хв), міжнародне нормалізоване відношення (МНВ; ум. од.), фібриноген (г/л), розчинні фібрин-мономерні комплекси (РФМК; мг/дл). Зазначені показники оцінювали в динаміці (до та після ПТ). Крім того, проведено комплексний аналіз даних анамнезу, клініко-інструментальних методів дослідження, лікувальної тактики та строків розвитку і клінічної картини радіаційних ускладнень.

Індекс маси тіла (за А. Кетле, кг/м²) інтерпретували згідно 3 класифікацією ВООЗ (1997р.): <18,5 кг/м² - знижена маса

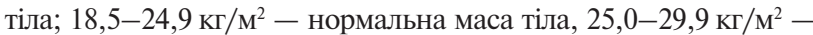

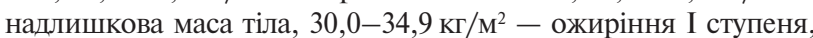
$35,0-39,9$ кг $/ \mathrm{M}^{2}-$ ожиріння II ступеня, $>40$ кг $/ \mathrm{M}^{2}-$ ожиріння III ступеня.

Дослідження проведено відповідно до основних біоетичних норм Гельсінської декларації Всесвітньої медичної асоціації «Етичні принципи медичних досліджень за участю людини у якості об’єкта дослідження» (1964-2013 рр.), Міжнародної настанови з етики для біомедичних досліджень Ради міжнародних організацій медичних наук (The Council for International Organizations of Medical Sciences - CIOMS, 2016), Конвенції Ради Свропи про права людини та біомедицину (2007), рекомендацій Комітету з біоетики при Президії НАМН України (2002), наказів МОЗ України від 23.09.2009 р. № 690, від 14.12.2009 р. № 944 та відповідних положень ВОО3 (World Health Organization), Міжнародної ради медичних наукових товариств та Міжнародного кодексу медичної етики (1983). Протоколи дослідження схвалені Комітетом з питань біоетики та деонтології ДУ «Інститут медичної радіології ім. С.П. Григор'єва НАМН України» (протокол від 22 січня 2019 р. № 1, протокол від 19 квітня 2019 р. № 8).

Задля комплексного аналізу клінічних та інструментальних даних історій хвороби створено стандартизовану цифрову інформаційну базу. Статистичну обробку одержаних результатів проведено з використанням прикладної програми для роботи з електронними таблицями «Microsoft Office Excel 2013» (Microsoft Corporation, США). Оцінку характеру розподілу величин у кожній групі вибіркової сукупності проводили з використанням W-критерію Шапіро - Вілка (Shapiro - Wilk test). Однорідність дисперсій визначали за критерієм Левена (Levene's test). Для оцінки значущості виявлених відмінностей досліджуваних показників проводили статистичний аналіз з використанням параметричного t-критерію Стьюдента у випадках нормального розподілу, непараметричний ранговий U-критерій Манна - Уітні (Mann - Whitney) - за його відсутності, кутове перетворення Фішера, критерію $\chi^{2}$ із поправкою Йєтса - під час обрахування результатів в альтернативній формі. Кількісну оцінку факторів ризику розвитку ППУ проведено з розрахунком значень відносного ризику (risk ratio) та відношення шансів (odds ratio). Відмінності вважали статистично значущими при $\mathrm{p}<0,05$. Цифрові дані у разі нормального розподілу величин наведені у вигляді « $\mathrm{M} \pm \mathrm{m} »$ $(\mathrm{M} \pm \mathrm{SE})$, де $\mathrm{M}$ - середне арифметичне значення, m (SE) стандартна похибка середнього арифметичного або М (95\% ДІ 5-95\%), де 95\% ДІ - 95\% довірчий інтервал (Confidence interval - CI). При ненормальному розподілі отриманих величин дані представлено у вигляді Me [LQ; UQ], де Ме - медіана, [LQ; UQ] - верхня межа нижнього (першого) квартиля (lower quartile - LQ) та нижня межа верхнього (третього) квартиля (upper quartile - UQ) [9].

\section{РЕЗУЛЬТАТИ ДОСЛІДЖЕННЯ \\ ТА ЇХ ОБГОВОРЕННЯ}

Проведене дослідження показало, що вік пацієнток у групі 3 фібротичними ППУ становив 56 [53; 60], а в групі із дегенеративними ППУ $-60[54 ; 67]$ років (рис. 1$)$.

Розподіл пацієнток за поширеністю процесу та клінічними групами згідно з Міжнародною класифікацією злоякісних новоутворень TNM (2017) та класифікацією FIGO (International Federation of Gynecology and Obstetrics, 2009) наведено в табл. 1.

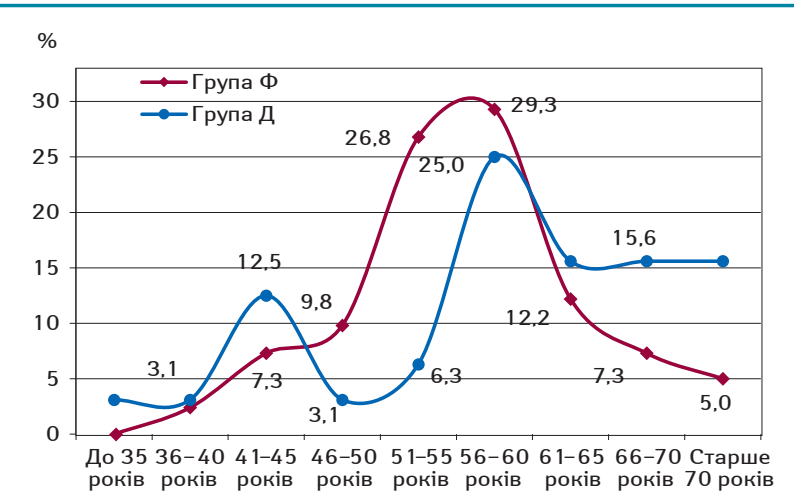

Рис. 1. Віковий розподіл хворих на РШМ з ППУ, n= 73 
Таблиця 1. Розподіл хворих на РШМ з ППУ за стадіями процесу та клінічними групами, $\mathrm{n}=73$

\begin{tabular}{lcccc}
\hline & & $\begin{array}{c}\text { Група } \mathbf{\Phi} \\
\text { (n=41), } \\
\text { абс. (\%) }\end{array}$ & $\begin{array}{c}\text { Група Д } \\
\text { (n=32), } \\
\text { абс. (\%) }\end{array}$ & $\begin{array}{c}\text { р- рівень } \\
\text { статистич- } \\
\text { ної вірогід- } \\
\text { ності розбіж- } \\
\text { ностей }\end{array}$ \\
\hline Стадія & I (T1N0 M0) & $13(31,7)$ & $4(12,5)$ & 0,2 \\
& II (T2 N0 M0) & $25(61,0)$ & $19(59,4)$ & 0,9 \\
& III (T3N0-1M0) & $2(4,9)$ & $8(25,0)$ & 0,8 \\
Клінічна & IV (T4N0-1M0-1) & $1(2,4)$ & $1(3,1)$ & 0,4 \\
група & I & $0(0,0)$ & $0(0,0)$ & - \\
& II & $12(29,2)$ & $11(34,4)$ & 0,8 \\
& III & $25(61,0)$ & $15(46,9)$ & 0,3 \\
\hline
\end{tabular}

У переважної більшості пацієнток обох груп відмічалася нормальна маса тіла (рис. 2). Надмірна ж маса тіла вдвічі частіше $(24,4$ проти $12,2 \%)$, ніж іiі дефіцит, відмічалася на тлі фібротичних ППУ, у той час як серед пацієнток з дегенеративними ППУ хворих з дефіцитом маси тіла та надмірною масою тіла було порівну - по 18,8\%.

Аналіз розподілу пацієнток за типом проведеного лікування (рис. 3) показав, що серед хворих з фібротичними ППУ переважали пацієнтки, яким виконували оперативне втручання у складі комплексного лікування - 68,4 проти 43,9\% хворих $з$ дегенеративними ППУ. Таким чином, відношення шансів розвитку фібротичних ППУ щодо дегенеративних після оперативного компонента лікування становить 2,8土0,49 (95\% ДІ 1,1-7,2). Це узгоджується з відомостями,

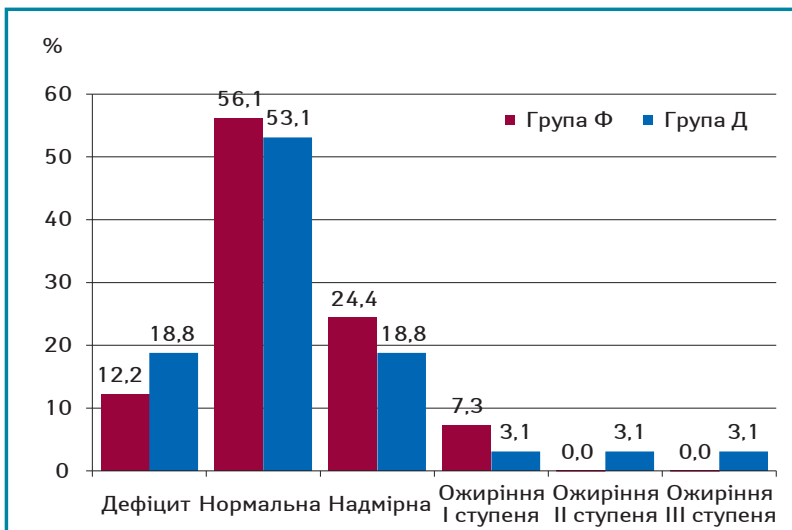

Рис. 2. Розподіл хворих на РШМ з ППУ за показниками маси тіла/зросту, $\mathrm{n}=73$

\begin{tabular}{|c|c|c|c|}
\hline \multirow{2}{*}{ дпТ+ВПпТ+ХТ } & $\%$ & \multirow{3}{*}{14.6} & \multirow{4}{*}{28.1} \\
\hline & 100 & & \\
\hline \multirow{2}{*}{ дпт+вппт } & 90 & & \\
\hline & 80 & 9,8 & \\
\hline дחТ+ВППТ+OB+XТ & 70 & 17.1 & \multirow[b]{2}{*}{21.9} \\
\hline дПТ+ВПпПт+ОВ & 60 & \multirow[b]{2}{*}{22,0} & \\
\hline дпт+Ов & 50 & & 18.8 \\
\hline $\mathrm{A \Pi T}+\mathrm{OB}+\mathrm{XT}$ & 30 & 17.1 & 9.4 \\
\hline \multirow[t]{2}{*}{ дпт+вппт+Гт } & 20 & \multirow{2}{*}{12,2} & \multirow{2}{*}{9.4} \\
\hline & 10 & & \\
\hline дпт+Xт & 0 & Група Ф & Група Д \\
\hline $\begin{array}{l}\text { Рис. 3. Розподіл хв } \\
\text { деного лікування, n} \\
\text { променева терапія; } \\
\text { танційна променева } \\
\text { XT - хіміотерапія }\end{array}$ & $\begin{array}{l}\text { рих } \\
73 . \\
\text { T- } \\
\text { тера }\end{array}$ & $\begin{array}{l}\text { РШМ з } \\
\text { Пт - вн } \\
\text { мональн } \\
\text {; ОВ - ог }\end{array}$ & $\begin{array}{l}\text { типом прове- } \\
\text { ьопорожнинна } \\
\text { сія; ДПТ - дис- } \\
\text { вне втручання; }\end{array}$ \\
\hline
\end{tabular}

що оперативне лікування в онкологічних пацієнтів може виступати передумовою підвищення радіочутливості тканин, що оточують пухлину, та розвитку променевих ускладнень лікування.

Також встановлено, що хіміотерапевтичний компонент комбінованого лікування отримували практично однакова кількість пацієнток - 51,2\% хворих групи Ф та 53,2\% - групи Д.

Аналіз наявності супутніх захворювань у хворих на РШМ показав, що як при фібротичних, так і при дегенеративних ППУ обтяжувальною соматичною патологією найчастіше виступали захворювання сечостатевої системи, кровообігу, нервової системи та органів травлення (рис. 4).

Аналіз динаміки гематологічних показників (рис. 5) показав, що на тлі проведення ПТ у хворих на РШМ з фібротичними ППУ відмічалося статистично вірогідне збільшення кількості еритроцитів на $5,7 \%(\mathrm{p}=0,045)$, гемоглобіну - на 9,1\% ( $\mathrm{p}=0,047)$, гематокриту - на $3,9 \%(\mathrm{p}=0,2)$ та ШОЕ - на $33,3 \%(\mathrm{p}=0,02)$, у той час як у пацієнток $з$ дегенеративними ППУ аналогічні показники мали протилежну тенденцію до змін - кількість еритроцитів зменшилася на $6,3 \%(\mathrm{p}=0,07)$, рівень гемоглобіну знизився на $0,8 \%(p=0,4)$, гематокрит - на 7,3\% ( $\mathrm{p}=0,037)$, а ШОЕ знизилася на $16,7 \%$ відносно показників до ПТ. Крім того, встановлено, що кількість лейкоцитів мала тенденцію до зменшення у пацієнток обох груп, проте у хворих з фібротичними ППУ вдвічі перевищувала аналогічний показник пацієнток з дегенеративними ППУ та становила відповідно 6,0 та 12,0\%.

Характеризуючи гематологічні показники до лікування, варто відзначити (табл. 2), що у пацієнток з фібротичними ППУ відмічався статистично вірогідно $(\mathrm{p}=0,017)$ нижчий на $5,0 \%$ КП, на 14,3\% менша кількість тромбоцитів $(\mathrm{p}=0,09)$ та на 5,9\% вищий показник гематокриту $(\mathrm{p}=0,2)$ відносно показників пацієнток з дегенеративними ППУ.

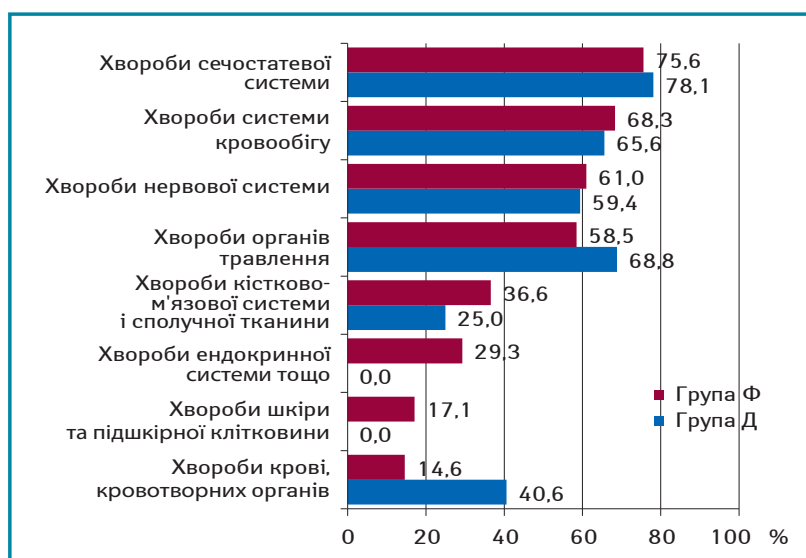

Рис. 4. Супутня патологія у хворих на РШМ з ППУ, $\mathrm{n}=73$

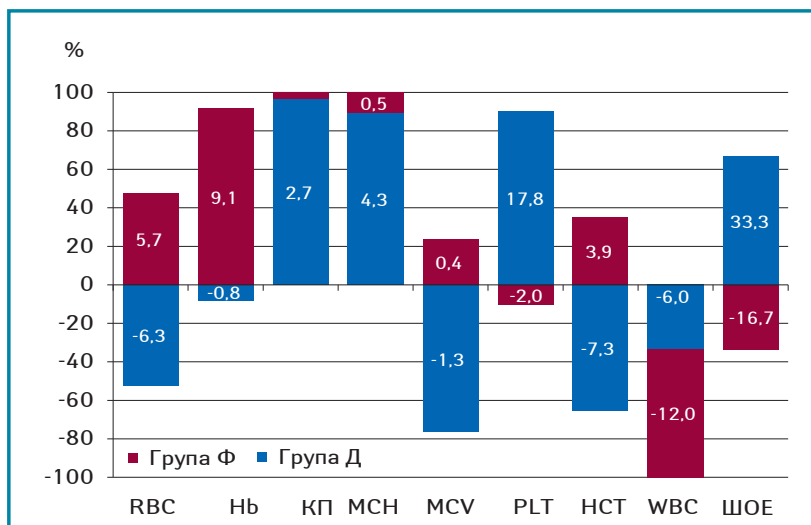

Рис. 5. Динаміка гематологічних показників хворих на РШМ після ПТ, $\mathrm{n}=73$ 


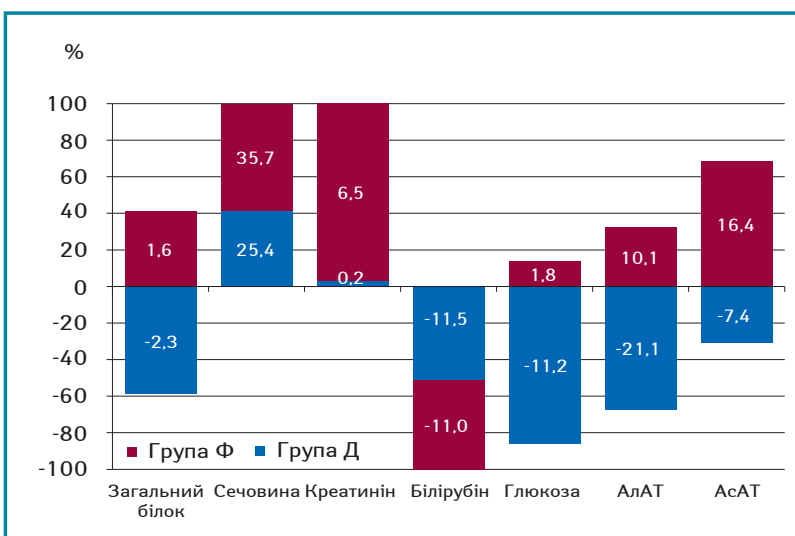

Рис. 6. Динаміка біохімічних показників хворих на РШМ після ПТ, $\mathrm{n}=73$

Розбіжності щодо інших показників не перевищували 5,0\% .

Характеризуючи динаміку біохімічних показників хворих на РШМ з ППУ (табл. 3), варто відзначити, що маркери цитолізу АлАТ та АсАТ мали різний вектор змін. Так, у пацієнток з фібротичними ППУ рівень АлАТ зріс на $10,1 \%$ $(\mathrm{p}=0,2)$, а AcAT - на 16,4\% (p=0,09), у той час як у пацієнток 3 дегенеративними ППУ рівень АлАТ знизився на 21,1\% $(\mathrm{p}=0,3)$, а AcAT - на 7,4\% ( $\mathrm{p}=0,4)$. Вказані зміни узгоджуються з даними про розвиток цитолітичного синдрому на тлі дегенеративних ППУ [7, 8].

Крім того, у пацієнток обох груп відмічено співставне зниження рівня білірубіну відповідно на 11,5 та $11,0 \%$ (p>0,05).

Також встановлено, що у пацієнток з фібротичними ППУ на тлі ПТ статистично вірогідно $(\mathrm{p}=0,001)$ підвищився рівень сечовини на $35,7 \%$ та рівень креатиніну - на $6,5 \%$ $(\mathrm{p}=0,5)$.

Водночас у пацієнток з дегенеративними ППУ на тлі ПТ спостерігалося зниження рівня глюкози крові на 11,2\%

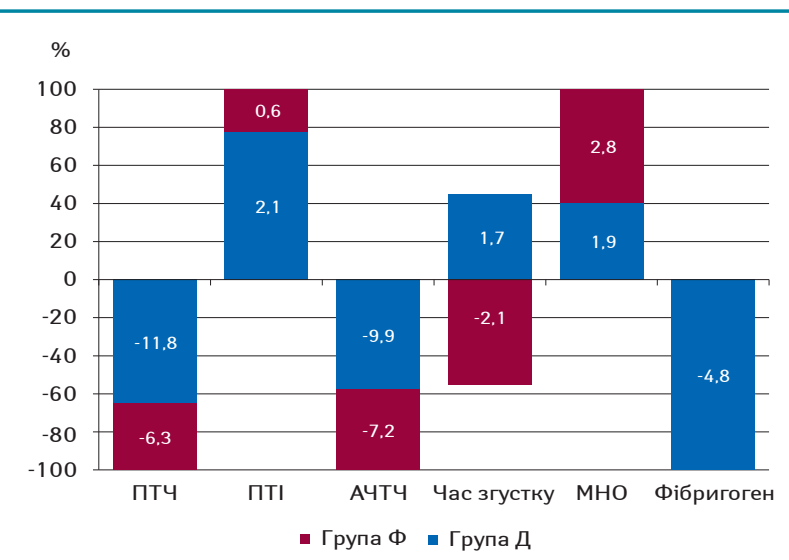

Рис. 7. Динаміка показників системи згортання крові хворих на РШМ після ПТ, $\mathrm{n}=73$

$(\mathrm{p}=0,2)$, на тлі незначного підвищення $(1,8 \%)$ аналогічного показника у пацієнток з фібротичними ППУ.

Характеризуючи вихідні біохімічні показники хворих на РШМ з фібротичними ППУ, варто звернути увагу на вищий на $11,6 \%(\mathrm{p}=0,2)$ рівень креатиніну та вищі $(\mathrm{p}>0,05)$ на 35,7 і 33,5\% показники АлАТ та АсАТ відповідно.

Оцінка показників системи згортання крові у хворих на РШМ з ППУ показала, що найвиразніші зміни відмічено з боку ПТЧ - зниження $(\mathrm{p}=0,1)$ на $11,8 \%(\mathrm{p}=0,4)$ у пацієнток 3 дегенеративними ППУ та на 6,3\% - у пацієнток з фібротичними ППУ, а також показника АЧТЧ - зниження $(\mathrm{p}=0,3)$ на 9,9\% у пацієнток з дегенеративними ППУ та на 7,2\% $(\mathrm{p}=0,06)-3$ фібротичними ППУ.

Характеризуючи вихідні показники системи згортання крові (табл. 4), варто відзначити вищий на $38,5 \%$ ( $\mathrm{p}=0,2)$ рівень фібриногену у пацієнток з фібротичними ППУ відносно хворих з дегенеративними ППУ.

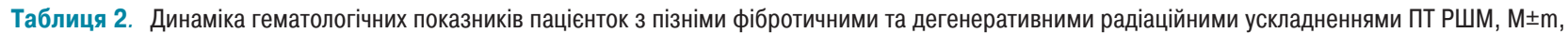
$95 \%$ ДI, Me [LQ; UQ]

\begin{tabular}{|c|c|c|c|c|c|c|c|c|}
\hline \multirow{2}{*}{$\begin{array}{c}\text { Досліджуваний показник, } \\
\text { одиниці вимірювання }\end{array}$} & \multicolumn{2}{|c|}{$\begin{array}{c}\text { Група } \Phi \\
(n=41)\end{array}$} & \multicolumn{2}{|c|}{$\begin{array}{c}\text { Група Д } \\
\text { (n=32) }\end{array}$} & \multicolumn{4}{|c|}{ Рівень статистичної вірогідності [\%] } \\
\hline & До ПТ & Після ПТ & До ПТ & Після ПТ & $p_{1}$ & $p_{2}$ & $p_{3}$ & $p_{4}$ \\
\hline Еритроцити, • $10^{12} / л$ & $3,9 \pm 0,09$ & $4,2 \pm 0,09$ ש & $4,2 \pm 0,13$ & $3,9 \pm 0,09 \bullet$ & 0,2 & 0,02 & 0,045 & 0,07 \\
\hline & (95\% ДІ 3,8-4,1) & (95\% ДІ 4,0-4,3) & (95\% ДІ 3,9-4,4) & (95\% ДІ $3,7-4,1)$ & {$[+5,1]$} & {$[-6,9]$} & {$[+5,7]$} & {$[-6,3]$} \\
\hline Гемоглобін, г/л & $121[113 ; 132]$ & $132[116 ; 142]$ a & $118[115 ; 123] \bullet$ & $117[106 ; 124] \bullet$ & $\begin{array}{c}0,02 \\
{[-2,5]}\end{array}$ & $\begin{array}{c}0,002 \\
{[-11,4]}\end{array}$ & $\begin{array}{l}0,047 \\
{[+9,1]}\end{array}$ & $\begin{array}{c}0,4 \\
{[-0,8]}\end{array}$ \\
\hline КП & $\begin{array}{l}0,91 \pm 0,011 \\
(95 \% \text { ДI } \\
0,89-0,93)\end{array}$ & $\begin{array}{l}0,91 \pm 0,009 \\
(95 \% \text { ДІ } \\
0,89-0,93)\end{array}$ & $\begin{array}{c}0,87 \pm 0,013 \bullet \\
(95 \% \text { मІ } \\
0,84-0,89)\end{array}$ & $\begin{array}{c}0,89 \pm 0,009 \\
(95 \% \text { मІ } \\
0,87-0,92)\end{array}$ & $\begin{array}{l}0,017 \\
{[-5,0]}\end{array}$ & $\begin{array}{c}0,1 \\
{[-2,2]}\end{array}$ & $\begin{array}{c}0,4 \\
{[+0,1]}\end{array}$ & $\begin{array}{l}0,048 \\
{[+2,7]}\end{array}$ \\
\hline $\begin{array}{l}\text { Середній вміст гемоглобіну } \\
\text { в еритроциті, пг }\end{array}$ & $30,3[29,3 ; 32,0]$ & $30,2[29,4 ; 31,6]$ & $28,9[27,5 ; 29,7] \bullet$ & $30,2[29,1 ; 30,8]$ & $\begin{array}{l}0,006 \\
{[-4,6]}\end{array}$ & $\begin{array}{c}0,1 \\
{[0,0]}\end{array}$ & $\begin{array}{c}0,6 \\
{[+0,5]}\end{array}$ & $\begin{array}{l}0,008 \\
{[+4,3]}\end{array}$ \\
\hline $\begin{array}{l}\text { Середній об'єм еритроци- } \\
\text { та, фл }\end{array}$ & $90,8[88,2 ; 94,8]$ & $91,2[89,8 ; 94,0]$ & $91,5[89,3 ; 92,0]$ & $90,3[88,4 ; 93,0]$ & $\begin{array}{c}0,4 \\
{[-0,8]}\end{array}$ & $\begin{array}{c}0,2 \\
{[-1,0]}\end{array}$ & $\begin{array}{c}0,5 \\
{[+0,4]}\end{array}$ & $\begin{array}{c}0,4 \\
{[-1,3]}\end{array}$ \\
\hline Тромбоцити, $\cdot 10^{9} / л$ & $223[182 ; 313]$ & $218[181 ; 169]$ & $191[174 ; 218]$ & $225[197 ; 281]$ ш & $\begin{array}{c}0,09 \\
{[-14,3]}\end{array}$ & $\begin{array}{c}0,2 \\
{[+3,0]}\end{array}$ & $\begin{array}{c}0,3 \\
{[-2,0]}\end{array}$ & $\begin{array}{c}0,04 \\
{[+17,8]}\end{array}$ \\
\hline Гематокрит, \% & $\begin{array}{c}36,9 \pm 0,79 \\
(95 \% \text { मा } \\
35,0-38,1)\end{array}$ & $\begin{array}{l}38,0 \pm 0,87 \\
(95 \% \text { मा } \\
36,3-39,7)\end{array}$ & $\begin{array}{c}38,7 \pm 0,92 \\
(95 \% \text { मा } \\
36,9-40,5)\end{array}$ & $\begin{array}{c}35,9 \pm 0,95 \bullet \\
(95 \% \text { मा } \\
34,1-37,8)\end{array}$ & $\begin{array}{c}0,2 \\
{[+5,9]}\end{array}$ & $\begin{array}{c}0,1 \\
{[-5,4]}\end{array}$ & $\begin{array}{c}0,2 \\
{[+3,9]}\end{array}$ & $\begin{array}{l}0,037 \\
{[-7,3]}\end{array}$ \\
\hline Лейкоцити, $\cdot 10^{9} /$ л & $5,0[3,9 ; 6,6]$ & $4,4[3,7 ; 5,2]$ & $5,0[4,3 ; 6,8]$ & $4,7[3,7 ; 6,4]$ & $\begin{array}{c}0,3 \\
{[0,0]}\end{array}$ & $\begin{array}{c}0,2 \\
{[+6,8]}\end{array}$ & $\begin{array}{c}0,2 \\
{[-12,0]}\end{array}$ & $\begin{array}{c}0,3 \\
{[-6,0]}\end{array}$ \\
\hline ШОЕ, мм/год & $12[7 ; 20]$ & $10[6 ; 15]$ & $12[5 ; 16]$ & $16[11 ; 25] \bullet \mathbf{\square}$ & $\begin{array}{c}0,3 \\
{[0,0]}\end{array}$ & $\begin{array}{c}0,001 \\
{[+60,0]}\end{array}$ & $\begin{array}{c}0,3 \\
{[-16,7]}\end{array}$ & $\begin{array}{c}0,02 \\
{[+33,3]}\end{array}$ \\
\hline
\end{tabular}

\section{Примітки:}

- $p \leqslant 0,05$ відносно показників пацієнтів I групи у відповідні терміни дослідження;

- $\mathrm{p} \leqslant 0,05$ відносно показників пацієнтів до пт;

$p_{1}$ - рівень статистичної вірогідності розбіжностей показників пацієнтів з фібротичними Ппу (група Ф) щодо показників пацієнтів з дегенеративними ППу (група Д) до Пт;

$\mathrm{p}_{2}$ - рівень статистичної вірогідності розбіжностей показників пацієнтів з фібротичними Ппу (група Ф) щодо показників пацієнтів з дегенеративними ППу (група Д) після ПТ;

$\mathrm{p}_{3}$ - рівень статистичної вірогідності розбіжностей показників пацієнтів з фібротичними ППу (група Ф) до та після Пт;

$\mathrm{p}_{4}$ - рівень статистичної вірогідності розбіжностей показників пацієнтів з дегенеративними ППУ (група Д) до та після Пт;

[] - в квадратних дужках наведена різниця відповідних показників у \%. 


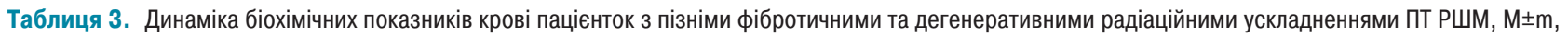
$95 \%$ ДI, Me [LQ; UQ]

\begin{tabular}{|c|c|c|c|c|c|c|c|c|}
\hline \multirow{2}{*}{$\begin{array}{c}\text { Досліджуваний показник, } \\
\text { одиниці вимірювання }\end{array}$} & \multicolumn{2}{|c|}{$\begin{array}{c}\text { Група } \Phi \\
(n=41)\end{array}$} & \multicolumn{2}{|c|}{$\begin{array}{c}\text { Група Д } \\
(\mathrm{n}=32)\end{array}$} & \multicolumn{4}{|c|}{ Рівень статистичної вірогідності [\%] } \\
\hline & До ПТ & Після ПТ & До ПТ & Після ПТ & $\mathbf{p}$ & & $n$ & $p_{4}$ \\
\hline Загальний білок, г/л & $\begin{array}{c}72,6 \pm 1,51 \\
(95 \% \text { ДІ } \\
69,7-75,6)\end{array}$ & $\begin{array}{c}71,1 \pm 0,90 \\
(95 \% \text { ДІ } \\
69,7-73,2)\end{array}$ & $\begin{array}{c}74,2 \pm 2,03 \\
(95 \% \text { ДІ } \\
70,2-78,2)\end{array}$ & $\begin{array}{c}72,6 \pm 1,13 \\
(95 \% \text { ДІ } \\
70,4-74,8)\end{array}$ & $\begin{array}{c}0,5 \\
{[-2,2]}\end{array}$ & $\begin{array}{c}0,4 \\
{[+1,6]}\end{array}$ & $\begin{array}{c}0,5 \\
{[+1,6]}\end{array}$ & $\begin{array}{c}0,2 \\
{[-2,3]}\end{array}$ \\
\hline Сечовина, ммоль/л & $4,20[3,70 ; 5,13]$ & $5,70[4,60 ; 7,20]$ & $4,35[3,68 ; 6,28] \boldsymbol{~}$ & $5,80[5,20 ; 6,75]$ घ & $\begin{array}{c}0,3 \\
{[+3,6]}\end{array}$ & $\begin{array}{c}0,2 \\
{[+1,8]}\end{array}$ & $\begin{array}{c}0,001 \\
{[+35,7]}\end{array}$ & $\begin{array}{c}0,01 \\
{[+25,4]}\end{array}$ \\
\hline Креатинін, мкмоль/л & $\begin{array}{c}72,4 \pm 3,62 \\
(95 \% \text { ДІ } \\
65,3-79,5)\end{array}$ & $\begin{array}{c}76,0 \pm 4,78 \\
(95 \% \text { ДI } \\
66,6-85,4)\end{array}$ & $\begin{array}{c}80,8 \pm 4,28 \\
(95 \% \text { ДI } \\
72,4-89,2)\end{array}$ & $\begin{array}{l}80,9 \pm 9,07 \\
(95 \% \text { дा } \\
63,2-98,7)\end{array}$ & $\begin{array}{c}0,2 \\
{[+11,6]}\end{array}$ & $\begin{array}{c}0,6 \\
{[+6,5]}\end{array}$ & $\begin{array}{c}0,5 \\
{[+6,5]}\end{array}$ & $\begin{array}{c}0,4 \\
{[+0,2]}\end{array}$ \\
\hline Білірубін, мкмоль/л & $14,2[11,9 ; 16,2]$ & $12,6[9,1 ; 16,2]$ & $13,9[11,6 ; 16,9]$ & $12,3[11,0 ; 15,6]$ & $\begin{array}{c}0,1 \\
{[-1,8]}\end{array}$ & $\begin{array}{c}0,3 \\
{[-2,4]}\end{array}$ & $\begin{array}{c}0,3 \\
{[-11,0]}\end{array}$ & $\begin{array}{c}0,2 \\
{[-11,5]}\end{array}$ \\
\hline Глюкоза, мкмоль/л & $5,5[5,3 ; 6,0]$ & $5,6[5,2 ; 6,2]$ & $5,8[5,2 ; 6,3]$ & $5,2[4,8 ; 5,7] \bullet$ & $\begin{array}{c}0,4 \\
{[+5,5]}\end{array}$ & $\begin{array}{c}0,03 \\
{[-8,2]}\end{array}$ & $\begin{array}{c}0,5 \\
{[+1,8]}\end{array}$ & $\begin{array}{c}0,2 \\
{[-11,2]}\end{array}$ \\
\hline АлАТ, мкмоль/год•л & $16,8[12,8 ; 27,4]$ & $18,5[16,2 ; 27,4]$ & $22,8[16,0 ; 30,9]$ & $18,0[11,4 ; 30,5]$ & $\begin{array}{c}0,2 \\
{[+35,7]}\end{array}$ & $\begin{array}{c}0,2 \\
{[-2,7]}\end{array}$ & $\begin{array}{c}0,2 \\
{[+10,1]}\end{array}$ & $\begin{array}{c}0,3 \\
{[-21,1]}\end{array}$ \\
\hline АсАТ, мкмоль/год•л & $18,6[15,7 ; 22,8]$ & $21,6[18,0 ; 26,3]$ & $24,4[16,8 ; 33,6]$ & $22,6[14,7 ; 29,4]$ & $\begin{array}{c}0,1 \\
{[+33,5]}\end{array}$ & $\begin{array}{c}0,3 \\
{[+4,6]}\end{array}$ & $\begin{array}{c}0,09 \\
{[+16,4]}\end{array}$ & $\begin{array}{c}0,4 \\
{[-7,4]}\end{array}$ \\
\hline
\end{tabular}

\section{Примітки:}

- $\mathrm{p} \leqslant 0,05$ відносно показників пацієнтів групи Ф у відповідні терміни дослідження;

- $\mathrm{p} \leqslant 0,05$ відносно показників пацієнтів до ПТ;

$\mathrm{p}_{1}$ - рівень статистичної вірогідності розбіжностей показників пацієнтів з фібротичними Ппу (група Ф) щодо показників пацієнтів з дегенеративними ППУ (група Д) до ПТ;

$\mathrm{p}_{2}$ - рівень статистичної вірогідності розбіжностей показників пацієнтів з фібротичними Ппу (група Ф) щодо показників пацієнтів 3 дегенеративними ППу (група Д) після Пт;

p $_{3}$ - рівень статистичної вірогідності розбіжностей показників пацієнтів з фібротичними Ппу (група Ф) до та після ПТ;

$\mathrm{p}_{4}$ - рівень статистичної вірогідності розбіжностей показників пацієнтів з дегенеративними ППУ (II група) до та після ПТ;

[] - в квадратних дужках наведена різниця відповідних показників у \%.

Таблиця 4. Динаміка показників системи згортання крові пацієнток з пізніми фібротичними та дегенеративними радіаційними ускладненнями

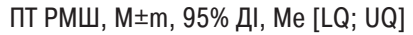

\begin{tabular}{|c|c|c|c|c|c|c|c|c|}
\hline \multirow{2}{*}{$\begin{array}{c}\text { Досліджуваний показник, } \\
\text { одиниці вимірювання }\end{array}$} & \multicolumn{2}{|c|}{$\begin{array}{c}\text { Група } \Phi \\
(n=41)\end{array}$} & \multicolumn{2}{|c|}{$\begin{array}{c}\text { Група Д } \\
(n=32)\end{array}$} & \multicolumn{4}{|c|}{ Рівень статистичної вірогідності [\%] } \\
\hline & До ПТ & Після ПТ & До ПТ & Після ПТ & $p_{1}$ & $p_{2}$ & $\mathbf{p}_{3}$ & $p_{4}$ \\
\hline ПТЧ, с & $15,0[15,0 ; 17,0]$ & $15,0[14,5 ; 17,0]$ & $17,0[15,2 ; 19,5]$ & $15,0[14,0 ; 16,0]$ & $\begin{array}{c}0,2 \\
{[+6,3]}\end{array}$ & $\begin{array}{c}0,2 \\
{[0,0]}\end{array}$ & $\begin{array}{c}0,4 \\
{[-6,3]}\end{array}$ & $\begin{array}{c}0,1 \\
{[-11,8]}\end{array}$ \\
\hline ПТІ, ум.од. & $93,3[87,0 ; 100,0]$ & $93,9[89,5 ; 100,0]$ & $92,3[89,5 ; 93,0]$ & $94,3[93,3 ; 100,0] \mathbf{\square}$ & $\begin{array}{c}0,2 \\
{[+1,1]}\end{array}$ & $\begin{array}{c}0,4 \\
{[+0,4]}\end{array}$ & $\begin{array}{c}0,3 \\
{[+0,6]}\end{array}$ & $\begin{array}{c}0,03 \\
{[+2,1]}\end{array}$ \\
\hline АЧТЧ, C & $\begin{array}{c}36,3 \pm 1,38 \\
(95 \% \text { ДІ } \\
33,6-39,0)\end{array}$ & $\begin{array}{c}33,7 \pm 1,01 \\
(95 \% \text { ДІ } \\
31,7-35,7)\end{array}$ & $\begin{array}{c}38,9 \pm 4,94 \\
(95 \% \text { ДІ } \\
29,2-48,5)\end{array}$ & $\begin{array}{c}35,5 \pm 1,50 \\
(95 \% \text { ДІ } \\
32,6-38,4)\end{array}$ & $\begin{array}{c}0,5 \\
{[+7,0]}\end{array}$ & $\begin{array}{c}0,3 \\
{[+5,3]}\end{array}$ & $\begin{array}{l}0,057 \\
{[-7,2]}\end{array}$ & $\begin{array}{c}0,3 \\
{[-9,9]}\end{array}$ \\
\hline Час згустку, хв & $7,30[5,45 ; 9,65]$ & $7,15[6,15 ; 9,35]$ & $7,30[6,85 ; 9,80]$ & $7,35[6,88 ; 9,26]$ & $\begin{array}{c}0,4 \\
{[0,0]}\end{array}$ & $\begin{array}{c}0,3 \\
{[+2,8]}\end{array}$ & $\begin{array}{c}0,5 \\
{[-2,1]}\end{array}$ & $\begin{array}{c}0,5 \\
{[+1,7]}\end{array}$ \\
\hline MHB & $1,07[1,00 ; 1,15]$ & $1,10[1,00 ; 1,20]$ & $1,08[1,07 ; 1,12]$ & $1,10[1,00 ; 1,10]$ & $\begin{array}{c}0,3 \\
{[+0,9]}\end{array}$ & $\begin{array}{c}0,3 \\
{[0,0]}\end{array}$ & $\begin{array}{c}0,5 \\
{[+2,8]}\end{array}$ & $\begin{array}{c}0,2 \\
{[+1,9]}\end{array}$ \\
\hline Фібригоген, г/л & $2,88[2,55 ; 4,71]$ & $2,88[2,22 ; 3,77]$ & $3,99[3,34 ; 5,18]$ & $3,80[3,20 ; 4,50] \bullet$ & $\begin{array}{c}0,2 \\
{[+38,5]}\end{array}$ & $\begin{array}{c}0,002 \\
{[+31,9]}\end{array}$ & $\begin{array}{c}0,2 \\
{[0,0]}\end{array}$ & $\begin{array}{c}0,4 \\
{[-4,8]}\end{array}$ \\
\hline РФМК, мг/дл & $3,50[3,50 ; 3,63]$ & $3,50[3,50 ; 3,50]$ & $3,50[3,50 ; 10,0]$ & $3,50[3,50 ; 3,50]$ & $\begin{array}{c}0,2 \\
{[0,0]}\end{array}$ & $\begin{array}{c}0,4 \\
{[0,0]}\end{array}$ & $\begin{array}{c}0,3 \\
{[0,0]}\end{array}$ & $\begin{array}{c}0,1 \\
{[0,0]}\end{array}$ \\
\hline
\end{tabular}

\section{Примітки:}

- $\mathrm{p} \leqslant 0,05$ відносно показників пацієнтів I групи у відповідні терміни дослідження;

- $p \leqslant 0,05$ відносно показників пацієнтів до Пт;

$p_{1}$ - рівень статистичної вірогідності розбіжностей показників пацієнтів з фібротичними Ппу (група Ф) щодо показників пацієнтів з дегенеративними ППу (група Д) до Пт;

$\mathrm{p}_{2}$ - рівень статистичної вірогідності розбіжностей показників пацієнтів з фібротичними Ппу (група Ф) щодо показників пацієнтів з дегенеративними ППу (група Д) після ПТ;

$\mathrm{p}_{3}$ - рівень статистичної вірогідності розбіжностей показників пацієнтів з фібротичними ППУ (група Ф) до та після ПТ;

$\mathrm{p}_{4}$ - рівень статистичної вірогідності розбіжностей показників пацієнтів з дегенеративними ПпУ (група Д) до та після Пт;

[] - у квадратних дужках наведена різниця відповідних показників у \%.

\section{ВИСНОВКИ}

1. У хворих на РШМ фібротичні та дегенеративні ППУ визначено у 32,3 та 25,2\% пацієнток відповідно.

2. Фібротичні ППУ у хворих на РШМ вдвічі частіше (24,4 проти 12,2\%) відмічають на тлі надмірної маси тіла, ніж на фоні ії дефіциту.

3. Відношення шансів розвитку фібротичних ППУ щодо дегенеративних після оперативного компонента лікування становить 2,8 $\pm 0,49$ (95\% ДІ 1,1-7,2).

4. У пацієнток з фібротичними пізніми променевими ускладненнями до лікування відмічалася більша $(\mathrm{p}=0,09)$ на 14,3\% кількість тромбоцитів, нижчий $(\mathrm{p}=0,2)$ на $38,5 \%$ рівень фібриногену, нижчий $(\mathrm{p}=0,2)$ на $11,6 \%$ рівень креатиніну та нижчі $(\mathrm{p}>0,05)$ на 35,7 і 33,5\% показники АлАТ та АсAТ відповідно відносно показників пацієнток з ускладненнями дегенеративного генезу.

\section{ПЕРСПЕКТИВИ ПОДАЛЬШИХ ДОСЛІДЖЕНЬ}

Отримані дані вказують на доцільність подальшого детального вивчення гомеостатичних зрушень у хворих на РШМ з метою виявлення прогностичних критеріїв розвитку ППУ після радіотерапії. 
Фінансування. Це дослідження є фрагментом планової науково-дослідної роботи ДУ «Інститут медичної радіології ім. С.П. Григор'єва НАМН України» «Визначення факторів прогнозу та індивідуалізація комплексного лікування пізніх променевих ускладнень» (номер державної реєстрації: 0118U001712, шифр теми: НАМН. 03.19, термін виконання: 2019-2021 рр.). Фінансування здійснюється за рахунок видатків з державного бюджету України.

Конфлікт інтересів. Автори рукопису свідомо засвідчують відсутність фактичного або потенційного конфлікту інтересів шодо результатів цієї роботи з фармацевтичними компаніями, виробниками біомедичних пристроїв, іншими організаціями, чиї продукти, послуги, фінансова підтримка можуть бути пов'язані з предметом наданих матеріалів.

Етичне твердження. Дослідження виконані згідно з міжнародними етичними нормами та схвалені Комітетом з питань біоетики та деонтології ДУ «Інститут медичної радіології ім. С.П. Григор'єва НАМН України» (протокол від 22 січня 2019 р. № 1, протокол від 19 квітня 2019 р. № 8). Ретроспективне дослідження не потребує отримання формальної згоди учасників. Ця стаття не містить даних щодо будь-яких досліджень на тваринах, виконаних будь-ким з авторів.

\section{СПИСОК ВИКОРИСТАНОЇ ЛІТЕРАТУРИ}

1. Горобцова, В. В., \& Ковалев., А. А. (2016). Рак шейки матки: актуальность проблемы, принципы лечения. Онкогинекология, 1(48), 63-66.

2. Дунаева, Е. А., Бойко, А. В., Демидова, Л. В., Вельшер, Л. З., Коробкова, Л. И., Коробкова, А. Ю., ...Лелеус, Т. А. (2015). Консервативные методы профилактики и лечения лучевых повреждений у больных злокачественными новообразованиями женских половых органов. Медицинская радиология и радиационная безопасность, 60(5), 59-73.

3. Іванкова, В. С., Нестеренко, Т. М., Барановська, Л. М., \& Хруленко, Т. В. (2016). Лікування і профілактика променевих ускладнень при радіотерапії раку шийки матки. Променева діагностика, променева терапія, 1, 60-64.

4. Крячок, И. А., Ульянченко, Е. О., Кадникова, Т. В., Титоренко, И. Б., Алексик, Е. М., Мартынчик, А. В., ... Рыспаева, Д. Э. (2017). Отдаленные осложнения лучевой терапии убольных со злокачественными новообразованиями. Клиническая онкология, 4(28), 59-62.

5. Оводенко, Д. Л., Хабас, Г. Н., Макарова, А. С., Серегин, А. А Голицына, Ю. С., \& Ашрафян, Л. А. (2019). Современные методы лечения больных местнораспространенным раком шейки матки. Акушерство и гинекология: новости мнения, обучение, 7(1), 68-74. doi: 10.24411/2303-9698-2019-11009

6. Міністерство охорони здоров'я України. (2014). Наказ № 236 від 2 квітня 2014 р. Уніфікований клінічний протокол первинної, вторинної (спеціалізованої), третинної (високоспеціалізованої) медичної допомоги. Дисплазія шийки матки. Рак шийки матки. Медицинские аспекты здоровья женщины, 5(80), 36-46.

7. Straub, J. M., New, J., Hamilton, C. D., Lominska, C., Shnayder, Y., \& Thomas, S. M. (2015). Radiation-induced fibrosis: mechanisms and implications for therapy. Journal of Cancer Research and Clinical Oncology, 141(11), 1985-1994. doi:10.1007/s00432-015-1974-6

8. Yarnold, J., \& Vozenin, M.-C. (2010). Brotons Pathogenetic mechanisms in radiation fibrosis. Radiotherapy and Oncology, 97, 149-161. doi: https://www.doi.org/ 10.1016/j.radonc.2010.09.002

9. Zar, J. H. (2014). Biostatistical analysis (5 ed.). Prentice-Hall, Englewood.

\section{Сравнительная характеристика}

гомеостатических сдвигов у пациенток

с фибротическими и дегенеративными

поздними радиационными осложнениями

лучевой терапии по поводу рака шейки матки

Ф.В. Гладких, Г.В. Кулинич

ГУ “Институт медицинской радиологии им. С.П. Григорьева Национальной академии медицинских наук Украины”, Харьков

Резюме. Лучевая терапия является важной составляющей лечения больных раком шейки матки (РШМ), однако в связи с особенностями синтопии шейки матки, прямой кишки, мочевого пузыря, мочеточников и др. лучевой нагрузке подвергаются практически все органы малого таза. Это является предпосылкой к развитию местных лучевых повреждений мягких тканей и органов, которые попадают в зону облучения. Цель - провести сравнительный анализ клинико-лабораторных показателей пациенток с поздними радиационными осложнениями фибротического и дегенеративного генеза после лучевой терапии по поводу РШМ для выявления критериев прогноза вектора развития поздних лучевых осложнений (ПЛО). Материалы и методы. Проведен ретроспективный анализ 254 историй болезни пациенток со злокачественными новообразованиями шейки матки. Отобраны 73 истории болезни пациенток, разделенных на две группы: Ф (41 пациентка) - больные с фибротическими ПЛО после лечения и Д (32 пациентки) больные с дегенеративными ПЛО после лечения. Результаты. Анализ динамики гематологических показателей показал, что на фоне проведения лучевой терапии (ЛТ) у больных РШМ с фибротическими ПЛО отмечалось статистически достоверное увеличение количества эритроцитов на 5,7\%, повышение гемоглобина - на 9,1\%, гематокрита - на $3,9 \%$ и повышение скорости оседания эритроцитов (СОЭ) на $33,3 \%$, в то время как у пациенток с дегенеративными ПЛО аналогичные показатели имели противоположную тенденцию к изменениям - количество эритроцитов уменьшилось на $6,3 \%$, уровень гемоглобина снизился на $0,8 \%$, гематокрит - на $7,3 \%$, а СОЭ - на $16,7 \%$ относительно показателей ЛТ. Кроме того, установлено, что количество лейкоцитов имело тенденцию к уменьшению у пациенток обеих групп, однако у больных с фибротическими ПЛО вдвое превышало аналогичный показатель пациенток с дегенеративными ПЛО и составило соответственно 6,0 и $12,0 \%$. Характеризуя динамику биохимических показателей больных РШМ с ПЛО стоит отметить, что маркеры цитолиза аланинаминотрансферазы (АлАТ) и аспартатаминотрансферазы (АсАТ) имели разный вектор изменений. Так, у пациенток с фибротическими ПЛО уровень АлАТ вырос на 10,1\%, а АсАт - на 16,4\%, в то время как у пациенток с дегенеративными ПЛО уровень АлАТ снизился на $21,1 \%$, а АсАТ - на 7,4\%. Указанные изменения согласуются с данными о развитии цитолитического синдрома на фоне дегенеративных ПЛО. Кроме того, у пациенток обеих групп отмечено сопоставимое снижение билирубина соответственно на 11,5 и $11,0 \%$. Также установлено, что у пациенток с фибротическими ПЛО на фоне ЛТ статистически достоверно повысился уровень мочевины на $35,7 \%$ и уровень креатинина - на 6,5\%. Выводы. У пациенток с РШМ фибротические и дегенеративные поздние лучевые осложнения определены у 32,3 и $25,2 \%$ больных соответственно. Фибротические поздние лучевые осложнения у больных РШМ в два раза чаще отмечают на фоне избыточной массы тела, чем на фоне ее дефицита - соответственно 24,4 и $12,2 \%$ пациенток. Отношение шансов развития фибротических ПЛО относительно дегенеративных после оперативного компонента лечения составляет 2,8土0,49 (95\% ДИ 1,1-7,2).

Ключевые слова: рак шейки матки; лучевая терапия; поздние лучевые осложнения; лучевой фиброз; лучевая язва.

\section{Comparative characteristics of homeostatic}

differences in patients with fibrotic and degenerative later radiation complexes of prouenvins

\section{F.V. Hladkykh, G.V. Kulinich}

SI "Grigoriev Institute for Medical Radiology, National Academy of Medical Sciences of Ukraine", Kharkiv

Resume. Radiation therapy is an important component of cervical cancer treatment, however, due to the peculiarities of cervical, rectum, bladder, ureter, and other synths. Practically all pelvic organs are exposed to radiation. This is a prerequisite for the development of local radiation damage to soft tissues and organs that enter the irradiation area. The aim is to conduct a comparative analysis of clinical and laboratory indicators of patients with late radiation complications of fibrotic and degenerative genesis after radiation therapy for cervical cancer to identify criteria for the prognosis of the vector of development of late radiation complications. Materials and methods. A retrospective analysis of 254 case histories of patients with malignant neoplasms of the cervix was performed. 73 case histories of patients were divided into two groups: $\mathrm{F}$ (41 patients) patients with fibrotic late radiation complications after treatment and $\mathrm{D}$ (32 patients) - patients with degenerative late radiation complications after treatment. Results. Analysis of the dynamics of hematological parameters showed that against the background of radiation therapy in patients with cervical cancer with fibrotic late radiation complications was observed statistically significant increase 


\section{Оригінальні статті / Original Articles}

in the number of erythrocytes by $5.7 \%$, Hemoglobin by $9.1 \%, 3.9 \%$ by $3 \%$ and erythrocyte sedimentation rate by $33.3 \%$, While in patients with degenerative late-onset complications similar indicators had the opposite tendency to change - erythrocyte count decreased by $6.3 \%$, hemoglobin level decreased by $0.8 \%$, Hematocrit decreased by $7.3 \%$ and erythrocyte sedimentation rate decreased by $16.7 \%$ relative to radiation therapy. In addition, it was found that the number of leukocytes tended to decrease in patients in both groups, but in patients with fibrotic late radiation complications twice exceeded the same indicator of patients with degenerative late radiation complications and were respectively 6.0 and $12.0 \%$. Characterizing the dynamics of biochemical parameters of patients with cervical cancer with late radiation complications, it is worth noting that the cytolysis markers of alanine aminotransferase and aspartate aminotransferase had different vector of changes. Thus, in patients with fibrotic late radiation complications, the level of alanine aminotransferase increased by $10.1 \%$, and aspartate aminotransferase - increased by $16.4 \%$, while in patients with degenerative late radiation complications, the level of aspartic aminotransferase decreased by $7.4 \%$. These changes are consistent with the data on the development of cytolysis syndrome on the background of degenerative late radiation complications. In addition, patients in both groups reported a combined decrease in bilirubin by 11.5 and $11.0 \%$, respectively. It was also found that in patients with fibrotic late radiation complications

with radiation therapy, the level of urea was statistically significantly increased by $35.7 \%$ and the level of creatinine by $6.5 \%$. Conclusions. In patients with cervical cancer, fibrotic and degenerative late radiation complications were identified in 32.3 and $25.2 \%$, respectively. Fibrotic late radiation complications are twice as common in patients with cervical cancer on the background of overweight than on the background of weight deficits -24.4 and $12.2 \%$ of patients, respectively. The ratio of the chances of developing fibrotic late radiation complications relative to degenerative after the operative component of treatment is $2.8 \pm 0.49$ (95\% CI 1.1-7.2).

Key words: cervical cancer; radiation therapy; late radiation complications; radiation fibrosis; radiation ulcer.

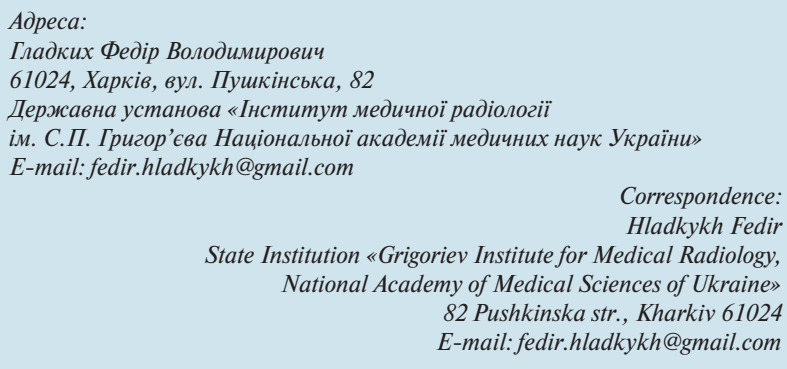

